DOI: 10.20472/IAC.2017.034.019

\author{
VELINKA GROZDANIĆ \\ Faculty of Law University of Rijeka, Croatia \\ MARISSABELL ŠKORIĆ \\ Faculty of Law University of Rijeka, Croatia \\ DALIDA RITTOSSA \\ Faculty of Law University of Rijeka, Croatia
}

\title{
MENTAL HEALTH LEGISLATION IN CROATIA: PAST, CURRENT STATE AND FUTURE CHALLENGES
}

\begin{abstract}
:
For the first time in Croatia the mental health legislation was enacted in 1997. Before the enactment of the Law/97 legal regulations concerning the legal status and compulsory detention of persons with mental difficulties were partial, inadequate, outdated and in most cases not applied in practice. Unfortunately, the first Croatian stand-alone law for mental health didn't resolve all the problems. Experience with the Law/97 shows that the mere existence of mental health legislation does not necessarily guarantee the protection of the human rights of people with mental disorders.

In the meantime high standards for protection of people with mental disabilities have already been accepted in numerous European and international documents. The 2006 UN Convention on the Rights of Persons with Disabilities has played a leading role in setting the new standards. Developments in the area of protection of people with mental health problems and specially the entry into force of the Convention in May 2008 triggered legislative reforms in many states including Croatia.

The new Law on Protection of Persons with Mental Difficulties was enacted in June 2014 and entered into force in January 2015. The main aim of the legislator has been to put forward legal solutions to improve a current legal position of persons suffering from mental disorders. One of the most important amendments is related to models of placement into psychiatric institution. An agent for healthcare decisions is a new institute introduced into Croatian legal system to directly and substantially enhance protection of persons with mental health problems. Another important improvement introduced in the Law concerns outpatient treatment of mentally incompetent persons who committed an unlawful act.

Making laws is the first step in protecting the rights of people with mental disorders, but after that it is necessary to organize educational lectures and workshops to prepare mental health professionals, lawyers as well as psychiatrists for implementation of the new Law. The NGO activists were included in educational programs and organisation of a campaign to promote the new human rights package of standards for people with mental disorders. A development of international standards and application of the Law/14 have been closely monitored and evaluated under the research activities within the Croatian Science Foundation project. Education, close cooperation of practitioners from different fields and opened discussions have been recognised as an important tool for promotion the rights of people with mental health problems increasing their empowerment in society.
\end{abstract}

\section{Keywords:}

mental health legislation, persons with mental difficulties, international standards, Croatia 